J. Lake Sci. (湖泊科学) , 2016, 28(6): 1293-1305

DOI 10. 18307/2016. 0615

(c) 2016 by Journal of Lake Sciences

\title{
鄱阳湖外围湖泊水体营养波动周年特征的比较湖沼学研究
}

\author{
匡武名 ${ }^{1,2,3}$, 张 萌 ${ }^{1,3 * *}$, 张金美 ${ }^{1,2,3}$, 何宗键 ${ }^{2}$, 彭希珑 ${ }^{2}$, 徐 军 $^{4}$, 刘足根 1,3 \\ ( 1 : 江西省环境保护科学研究院,南昌 330029) \\ (2: 南昌大学资源环境和化工学院, 南昌 330031) \\ ( 3 : 江西省环境保护工程技术研究中心, 南昌 330029) \\ (4: 中国科学院水生生物研究所,武汉 430072)
}

摘 要: 近年来, 我国最大淡水湖泊湿地鄱阳湖的水体富营养化趋势明显且日益受到各方关注, 而对鄱阳湖湖体外围各 类浅水湖泊富营养化情况及其动态却了解颇少. 为深人了解鄱阳湖外围不同湖泊的富营养化现状、季节动态及驱动机 制,于 2014-2015 年对毗邻鄱阳湖南岸的南昌市大小不同的 3 个城市或城郊浅水湖泊 (青山湖、瑶湖、军山湖) 水质参数 和营养状态进行周年观测. 结果表明, 青山湖、瑶湖和军山湖的高镇酸盐指数范围分别在 2.6 4.5、2.1 4.6 和 $1.6 \sim 1.9$ $\mathrm{mg} / \mathrm{L}$ 之间, 仅军山湖目前未受到有机物污染影响, 3 个湖泊两两之间均呈极显著差异. 青山湖和瑶湖水体总氮 ( TN)、总 磷 (TP) 浓度远高于湖泊富营养化转换的阈值 ( TN : $0.20 \mathrm{mg} / \mathrm{L}, \mathrm{TP}: 0.02 \mathrm{mg} / \mathrm{L}$ ), 且 TP 污染最为严重, 仅达到地表水 $\mathrm{N} \sim$ 劣 $\mathrm{V}$ 类标准. 在 3 个湖泊中, 水体氮主要以可溶性态氮的形态占优势, 水体磷形态除了军山湖外, 另外 2 个湖泊主要以颗 粒态磷占优势. 青山湖、瑶湖和军山湖的叶绿素 a(Chl.a) 浓度范围分别为 34.65 184.48、7.66 120.67 和 2.42 17.41 $\mu \mathrm{g} / \mathrm{L}$, 各 湖泊的 Chl.a 浓度均在冬季达到最低值, 且军山湖与其他 2 个湖泊的 Chl.a 浓度均呈极显著性差异, 青山湖与瑶湖无显著 差异. 基于综合营养状态指数法对 3 个湖泊的营养状态进行评价发现, 青山湖富营养化程度最高, 已达到轻一中度富营养 的稳定富营养状态; 其次为瑶湖, 营养状态不稳定, 在中营养-轻度富营养-中度富营养水平之间巨幅波动; 军山湖相对最 低, 全年整体处于贫营养-中营养状态之间, 处于波动上升的趋中营养状态. 同时发现 3 个湖泊的水体富营养化程度的年 内波动依赖于不同的水温环境, 水温是以上 3 个亚热带浅水湖泊富营养化程度年内季度波动的重要影响因子之一. Pearson 相关分析还发现, 3 个湖泊的 Chl.a 浓度均与水柱 TN 和 TP 浓度呈显著正相关, 其中青山湖和军山湖的水柱 Chl.a 浓度与总溶解性氮和总溶解性磷浓度均呈极显著正相关关系. 整体来说, 水柱氮是影响 3 个湖泊水环境特征的主导因子 之一, 磷是 2 个富营养化湖泊的主导影响因子, 在富营养化湖泊控制和削减磷营养盐输人的同时, 应考虑如何有效降低氮 的输人, 并着力控制中温季节 (水温为 $152^{\circ} \mathrm{C}$ ) 的营养输人和快速富营养化风险防控; 中营养湖泊 (军山湖) 应在控制磷 的输人和消减水柱氮上进行系统调控, 尤其重视高温季节 (水温 $>25^{\circ} \mathrm{C}$ ) 的防控与预警, 这将对鄱阳湖外围浅水湖泊的水 环境保护和治理提供重点方向与新型管理思路.

关键词: : 外围浅水湖泊;鄱阳湖水系;富营养化;综合评估;周年动态;比较湖沼学

\section{Comparative limnological study on annual dynamic pattern of nutrients in water column of three suburb lakes adjacent to Lake Poyang}

KUANG Wuming ${ }^{1,2,3}$, ZHANG Meng ${ }^{1,3 * *}$, ZHANG Jinmei ${ }^{1,2,3}$, HE Zongjian ${ }^{2}$, PENG Xilong ${ }^{2}$, XU Jun ${ }^{4}$ \& LIU Zugen ${ }^{1,3}$

(1: Jiangxi Academy of Environmental Sciences, Nanchang 330029, P.R.China)

(2: Department of Resources, Environmental \& Chemical Engineering, Nanchang University, Nanchang 330031, P.R.China)

(3: Environmental Pollution Engineering Center of Jiangxi, Nanchang 330029, P.R.China)

(4: Institute of Hydrobiology, Chinese Academy of Sciences, Wuhan 430072, P.R. China)

* 国家水体污染控制与治理科技重大专项 (2012ZX07501001-06)、国家自然科学基金项目 (31200360, C030604, 31400402 )、江西省科技计划项目 (20112BBG70014,20122BBF60101,20133BBG70001) 和江西省青年科学基金项目 (20114BAB213004) 联合资助.2015 - 10-28 收稿; 2016-03-01 收修改稿. 匡武名 (1991 ), 男, 硕士研究生; E-mail:kuangWMin@163.com.

** 通信作者;E-mail: tomdeshiye@126.com. 
Abstract: The increasing eutrophication of Lake Poyang, the largest freshwater Chinese lake, has taken more and more attention in recent years, but the eutrophication of shallow lakes around Lake Poyang are known rather little. An annual limnological investigation was conducted in the year of 2014-2015 in 3 typical shallow lakes, adjacent to the southwest bank of Lake Poyang at the suburb of Nanchang City, Jiangxi Province. Parameters of the water quality and eutrophic level in the three lakes were time-serially monitored to deeply understand the seasonally dynamics and the driving mechanism. Results showed that the variation of $\mathrm{COD}_{\mathrm{Mn}}$ in Lake Qingshan, Lake Yaohu and Lake Junshan ranged from 2.6-4.5 mg/L, 2.1-4.6 mg/L and 1.6-1.9 mg/L, respectively. Only Lake Junshan was still not affected by the organic pollution, and significant differences were found between each other among the three lakes. The contents of total nitrogen (TN) and total phosphorus (TP) in the water column of Lake Qingshan and Lake Yaohu largely exceeded the thresholds for eutrophic regime shifts (TN: $0.20 \mathrm{mg} / \mathrm{L}, \mathrm{TP}: 0.02 \mathrm{mg} / \mathrm{L}$ ), while the concentration of TP was only in Class IV-below V. The main form of nitrogen in the three lakes was soluble, and the main form of phosphorus in these lake were all particulate, except Lake Junshan. The contents of Chl.a in Lake Qingshan, Lake Yaohu and Lake Junshan were 34.65$184.48 \mu \mathrm{g} / \mathrm{L}, 7.66-120.67 \mu \mathrm{g} / \mathrm{L}$ and $2.42-17.41 \mu \mathrm{g} / \mathrm{L}$, respectively, and the contents were all lowest in winter. Lake Junshanwas significantly different from both Lake Qingshan or Lake Yaohu in the Chl.a contents, but no significant difference in the Chl.a contents between Lake Qingshan and Lake Yaohu. The trophic states of the three lakes has been assessed with a synthesized trophic state index (TLI).It's found that Lake Qingshan was in the highest eutrophic level( from mild to moderate eutrophication), followed by Lake Yaohu (from mesotrophication to moderate eutrophication) and Lake Junshan (from oligotrophication to mesotrophication) during the studying period. Water temperature was found as one of the important environmental factors affecting the seasonal trophic fluatuation of these lakes. The significant positive relationships were calculated between Chl.a and TN or TP in water column of all lakes through Pearson correlation analysis, while Chl.a was tightly positively correlated with TDN and TDP only in Lake Qingshan and Lake Yaohu. Overall, nitrogen was one of the dominant factors affecting the environmental characteristics in these lakes, and phosphorus was the predominant factor affecting two eutrophic lakes. In the process of nutrient control, effective reduction of the nitrogen input should be considered in the eutrophic lakes while lowering the phosphorus discharge, especially, during the period of middle water temperature $\left(15-25^{\circ} \mathrm{C}\right)$, and systematical regulation should be conducted in the mesotrophic lake (e.g. Lake Yaohu) through the combination of $\mathrm{N}$ reduction and $\mathrm{P}$ sources control, in particular, during the period of high water temperature at more than $25^{\circ} \mathrm{C}$.It would provide a new way to protect and manage water environment of these shallow lakes around Lake Poyang. Keywords: Shallow lake; Poyang Basin; eutrophication; synthesized assessment; annual dynamics; comparative limnology

当前,湖泊水体富营养化是全球性的生态学问题 ${ }^{[1]}$. 近 30 年来, 我国湖泊水体富营养化问题越来越严 峻 ${ }^{[2-3]}$, 我国富营养化湖泊比例从 1980s 后期的 44\%上升至 1990s 后期的 77\%, 直至 2003 年的 $85 \%$,水体富 营养化的程度和范围呈明显扩大发展趋势 ${ }^{[4]}$. 长江中下游地区是我国八大内陆天然湖泊分布区之一,集中 了我国约 $2 / 3$ 的淡水湖泊,与西南高原深水湖泊不同的是,该地区湖泊以丘陵一平原浅水型为主,区域内城 市、城郊湖泊富营养化问题突出, 多处于中营养一富营养一超富营养化阶段, 因此控制和减缓湖库的富营养 化是当前关注的焦点问题.

江西是长江中下游地区湖泊数量多、容量大的省份, 常年水面面积 $1 \mathrm{~km}^{2}$ 以上的天然湖泊达 86 个,水面 总面积为 $3802 \mathrm{~km}^{2}$. 然而, 有关资源丰沛的江西水系的富营养化评估和研究报告相对较少, 只对鄱阳湖、五 大河流和袁河等大型流域进行过部分研究 ${ }^{[5-8]}$. 然而,近年来以鄱阳湖为代表的湖体水质呈明显下降趋势, 富营养化风险加大 ${ }^{[9-10]}$, 而鄱阳湖外围的城市和城郊湖泊富营养化现象日益突出, 鄱阳湖前置库的污染和干 扰程度加剧势必阻碍鄱阳湖 “清水通道” 的构建, 降低鄱阳湖人湖来水的水质. 目前有关鄱阳湖外围湖泊富 营养化的相关研究报道极少, 本研究以长江中下游流域江西境内鄱阳湖湖体外围 3 个面积大小和富营养化 程度梯度明显的典型亚热带天然浅水湖泊 (青山湖、瑶湖和军山湖) 为研究对象, 通过连续野外湖泊调查、室 内对比分析等手段,进行 3 个典型湖泊富营养化现状评估、污染特征及驱动机制研究, 以期为理解南方生活 源污染型主导的城市毗邻湖泊富营养化发展、驱动与时空变化特征提供新的研究视角, 为欠发达的南方省 份城镇湖泊保护和治理提供参考依据.

\section{1 材料与方法}

\section{1 湖泊概况}

青山湖 ( $28^{\circ} 41^{\prime} \sim 28^{\circ} 43^{\prime} \mathrm{N}, 115^{\circ} 55^{\prime} \sim 115^{\circ} 56^{\prime} \mathrm{E}$ ) 是南昌市城区最大内湖, 距离鄱阳湖岸最小距离 $30 \mathrm{~km}$, 
水面面积为 $4.00 \mathrm{~km}^{2}$, 平均水深为 $1.75 \mathrm{~m}$, 最大水深为 $3.2 \mathrm{~m}$, 北宽南窄, 现为南昌市著名的水上娱乐风景游 览区.

瑶湖 $\left(28^{\circ} 38^{\prime} \sim 28^{\circ} 44^{\prime} \mathrm{N}, 116^{\circ} 02^{\prime} \sim 116^{\circ} 05^{\prime} \mathrm{E}\right.$ ) 是南昌市最大的内陆天然湖泊, 距离鄱阳湖岸最小距离 20 $\mathrm{km}$, 湖面呈流线型, 自南向北分为上瑶湖、中瑶湖、下瑶湖, 水面面积为 $15.25 \mathrm{~km}^{2}$, 水产养殖年产量约为 $1000 \sim$ $1500 \mathrm{t}$. 上瑶湖周边分布有昌东高校园区、江西氨厂、渔业养殖基地以及 2010 年初为筹备 “七城会” 在此段动 工建造并于 2011 年 7 月通过验收的江西瑶湖国际水上运动中心; 而中上瑶湖段周边以水稻田分布为主 ${ }^{[11]}$.

军山湖 $\left(28^{\circ} 24^{\prime} \sim 28^{\circ} 38^{\prime} \mathrm{N}, 116^{\circ} 15^{\prime} \sim 16^{\circ} 28^{\prime} \mathrm{E}\right)$ 坐落于江西省进贤县, 是中国境内最大的淡水湖泊鄱阳 湖的封闭性子湖, 与鄱阳湖湖体阻隔近 60 年, 与鄱阳湖岸仅一坝 $(\approx 20 \mathrm{~m})$ 之隔, 水位高于湖体 $1 \sim 2 \mathrm{~m}$, 是鄱 阳湖典型的前置库, 水面面积为 $213.3 \mathrm{~km}^{2}$, 最大水深为 $7.0 \mathrm{~m}$, 平均水深为 $3.82 \mathrm{~m}$, 其原属鄱阳湖南部一大湖 汊, 与金溪湖、青岗湖相连, 它既有悠久的文化历史背景又有丰富的农产养殖品 (如名扬海内外的军山湖大 闸蟹), 军山湖水质纯净, 是国家水质良好大型湖泊之一 ${ }^{[12-13]} .3$ 个湖泊的基础数据概况见表 1.

表 1 南昌典型 3 个浅水湖泊湖沼学基础信息特征

Tab.1 The limnological characteristics for the three shallow urban lakes of Nanchang City in south Lake Poyang

\begin{tabular}{|c|c|c|c|c|c|c|c|}
\hline 湖泊 & $\begin{array}{c}\text { 水面面积/ } \\
\mathrm{km}^{2}\end{array}$ & $\begin{array}{l}\text { 最大水 } \\
\text { 深 } / \mathrm{m}\end{array}$ & $\begin{array}{l}\text { 平均水 } \\
\text { 深 } / \mathrm{m}\end{array}$ & $\begin{array}{c}\text { 湖泊容积 } \\
\mathrm{m}^{3}\end{array}$ & 湖泊用途 & $\begin{array}{l}\text { 湖泊 } \\
\text { 形状 }\end{array}$ & $\begin{array}{c}\text { 自然岸 } \\
\text { 带率 }\end{array}$ \\
\hline 青山湖 & 4.00 & 3.2 & 1.75 & $8.7 \times 10^{6}$ & 景观水体 & “弓”形 & $35 \%$ \\
\hline 瑶湖 & 15.25 & 3.8 & 1.60 & $41.5 \times 10^{6}$ & $\begin{array}{c}\text { 水产养殖( 鲢、鳙、草, 产量约 } \\
1000 \sim 1500 \text { t) 和景观水体 }\end{array}$ & 流线型 & $54 \%$ \\
\hline 军山湖 & 213.30 & 7.0 & 3.82 & $15.6 \times 10^{8}$ & $\begin{array}{l}\text { 水产养殖( 中华线螯蟹、鲌、 } \\
\text { 鲢、鳙等, 渔产量约 } 4000 \text { t) }\end{array}$ & 三角叉形 & $86 \%$ \\
\hline
\end{tabular}

\section{2 数据采集}

采样时间为 2014 年 10 月一 2015 年 7 月,野外采样工作均安排于每月的下旬完成. 采样点位按照均匀 布点法进行布设, 青山湖共布设 4 个点位; 考虑到瑶湖体呈流线型, 共布设 7 个点位; 军山湖共布设 5 个点位 ( 具体分布情况见图 1).

\section{3 测定与评价方法}

水质理化测定指标包括水温 $(\mathrm{T})$ 、溶解氧 $(\mathrm{DO})$ ) $\mathrm{pH}$ 值、浊度 $(\mathrm{TURB})$ 、电导率 $(\mathrm{COND})$ 、透明度 $(\mathrm{SD})$ 、氧化 还原电位 $(\mathrm{ORP})$ 、矿化度 $(T D S) 、$ 总氮 $(\mathrm{TN})$ 、总磷 $(\mathrm{TP})$ 、氨氮 $\left(\mathrm{NH}_{3}-\mathrm{N}\right)$ 、硝态氮 $\left(\mathrm{NO}_{3}^{-}-\mathrm{N}\right)$ 、正磷酸盐 $\left(\mathrm{PO}_{4}^{3-}-\mathrm{P}\right)$ 、 可溶性总氮 (TDN)、可溶性总磷 (TDP)、叶绿素 $\mathrm{a}(\mathrm{Chl} . \mathrm{a})$ 以及高锰酸盐指数 $\left(\mathrm{COD}_{\mathrm{Mn}}\right)$ 等. 采集现场利用塞氏 黑白盘测定 SD 和水深, 其中 T、DO、 $\mathrm{pH} 、$ COND、ORP 和 TDS 等采用便捷式水质分析仪 YSI( Yellow Spring, $\mathrm{OH} 45387 \mathrm{USA}$ ) 进行现场监测. 过滤水是通过 $0.45 \mu \mathrm{m}$ GF/C 膜 (Waterman) 抽滤所得. 过滤水中 TDN、TDP 及 $\mathrm{PO}_{4}^{3-}-\mathrm{P}$ 和原水中 $\mathrm{TN} 、 \mathrm{TP} 、 \mathrm{NH}_{3}-\mathrm{N} 、 \mathrm{COD}_{\mathrm{Mn}}$ 、 Chl. a 等监测项目均根据《水和废水监测分析方法》 ${ }^{[14]}$ 进行. 湖 泊富营养状态评价采用《湖泊 (水库) 富营养化评价方法及分级技术规定》中的 $T L I(\Sigma)$ ( 综合营养状态指 数) 评价方法与标准测定 ${ }^{[15]}$, 其计算公式为:

$$
\operatorname{TLI}(\Sigma)=\sum_{j=1}^{m} W_{j} \cdot \operatorname{TLI}(j)
$$

式中, $W_{j}$ 为第 $j$ 种因子的营养状态指数的相关权重, $T L I(j)$ 为第 $j$ 种因子的营养状态指数, $m$ 为评价因子个 数. 采用 $0 \sim 100$ 的一系列连续数字对湖泊营养状态进行分级: $T L I(\Sigma)<30$ 为贫营养; $30 \leqslant T L I(\Sigma) \leqslant 50$ 为中 营养; $T L I\left(\sum\right)>50$ 为富营养, 其中 $50<T L I\left(\sum\right) \leqslant 60$ 为轻度富营养, $60<T L I\left(\sum\right) \leqslant 70$ 为中度富营养, $T L I\left(\sum\right)>$ 70 为重度富营养.

\section{4 数据处理}

采用 SPSS 19.0 软件对实验数据进行统计分析, 相关性分析采用 Pearson 或 Spearman 相关性分析, 差异 性比较用单因素方差分析. 各水质指标的季节变化以季度算术平均值进行比较, 2014 年 10-11 月为秋季, 2014 年 12 月- 2015 年 1 月为冬季, 2015 年 3-4 月为春季, 2015 年 6-7 月为夏季; 水温分为低、中、高 3 


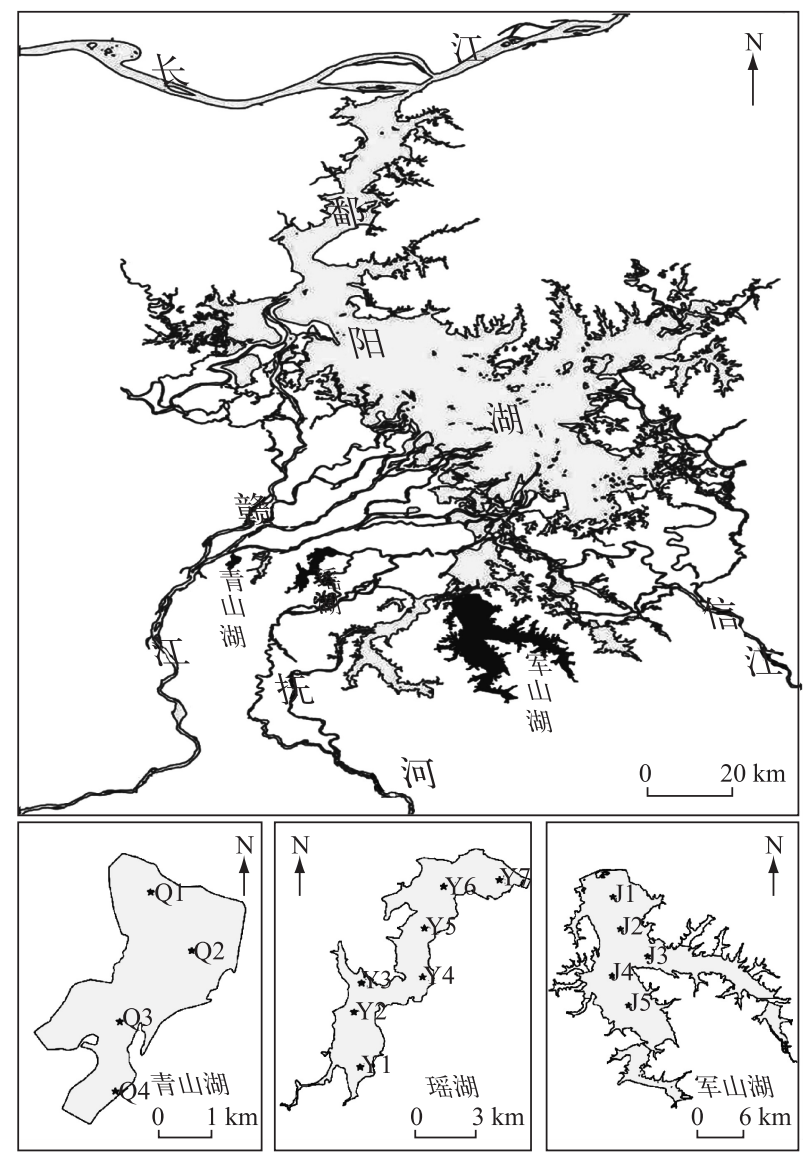

图 1 鄱阳湖附近青山湖、瑶湖和军山湖采样点位分布

Fig.1 The sketch of sampling points of Lake Qingshan, Lake Yaohu and Lake Junshan adjacent to the Lake Poyang 级, 其中水温 $\mathrm{T}<15^{\circ} \mathrm{C}$ 为低温, $15^{\circ} \mathrm{C} \leqslant \mathrm{T} \leqslant 25^{\circ} \mathrm{C}$ 为中温, $\mathrm{T}>25^{\circ} \mathrm{C}$ 为高温. 采用 ArcGIS、Excel 2003 软件作图.

\section{2 结果}

\subsection{3 个湖泊基本理化指标现状与对比}

3 个湖泊在水文过程、人为干扰及湖泊利用类型等方面各不相同, 在一些理化指标上存在明显的差异 (表 2). 3 个湖泊 $\mathrm{pH}$ 值范围为 7.5 8.7, 青山湖和瑶湖的 $\mathrm{pH}$ 高于军山湖, 这是由于期间为净化湖水消杀蓝 藻而投人大量生石灰和生物再生杀菌剂, 从而导致湖水 $\mathrm{pH}$ 值升高; $\mathrm{SD}$ 范围为 $0.33 \sim 1.20 \mathrm{~m}$, 不同湖泊存在 显著差异, 其中军山湖地处农村偏僻地区, 受人为影响较小、植被覆盖率高, SD 显著高于其他湖泊; 电导率 $80 \sim 201 \mu \mathrm{S} / \mathrm{cm}, 3$ 个湖泊之间差异较大; 浊度范围为 $10.7 \sim 50.4 \mathrm{NTU}$, 与 3 个湖泊 SD 的变化一致; ORP 范围 为 $96.0 \sim 131.5 \mathrm{mV}$, 青山湖最低, 军山湖最高 ; 消光系数 $K_{d}$ 表现为青山湖 $>$ 瑶湖 $>$ 军山湖.

\subsection{3 个湖泊水体环境特征参数的变化与对比}

高锰酸盐指数作为有机污染物指标, 当其超过 $4 \mathrm{mg} / \mathrm{L}$ 时, 表示水体已受到有机污染 ${ }^{[16]}$, 除了青山湖秋 季和瑶湖夏季受到有机污染外 (图 2), 其他季节 $\mathrm{COD}_{\mathrm{Mn}}$ 浓度均低于 $4 \mathrm{mg} / \mathrm{L}$, 优于地表水 II 类标准. 青山湖和 瑶湖 $\mathrm{COD}_{\mathrm{Mn}}$ 浓度范围分别为 $2.6 \sim 4.5$ 和 $2.1 \sim 4.6 \mathrm{mg} / \mathrm{L}$, 青山湖和瑶湖变化情况表现类似, 在冬季降低, 其他 季节有所升高. 军山湖 $\mathrm{COD}_{\mathrm{Mn}}$ 浓度范围为 $1.6 \sim 1.9 \mathrm{mg} / \mathrm{L}$, 均值为 $1.7 \mathrm{mg} / \mathrm{L}$, 在调查的月份当中均优于 I 类标 准,各季节之间无明显变化趋势. 3 个湖泊两两之间 $\mathrm{COD}_{\mathrm{Mn}}$ 浓度呈极显著差异 $(P<0.01)$. 
表 2 青山湖、瑶湖和军山湖基本理化指标数据

Tab.2 The basic physical and chemical indicators data of Lake Qingshan, Lake Yaohu and Lake Junshan

\begin{tabular}{lccccccccc}
\hline 湖泊 & $\mathrm{pH}$ 值 & $\begin{array}{c}\mathrm{DO} / \\
(\mathrm{mg} / \mathrm{L})\end{array}$ & $\begin{array}{c}\text { 透明度/ } \\
\mathrm{m}\end{array}$ & $\begin{array}{c}\text { 矿化度/ } \\
(\mathrm{mg} / \mathrm{L})\end{array}$ & $\begin{array}{c}\text { 电导率/ } \\
(\mu \mathrm{S} / \mathrm{cm})\end{array}$ & $\begin{array}{c}\text { 浊度/ } \\
\mathrm{NTU}\end{array}$ & $\begin{array}{c}\mathrm{ORP} / \\
\mathrm{mV}\end{array}$ & $\begin{array}{c}\mathrm{PAR}^{*} / \\
\mu \mathrm{E}\end{array}$ & $\begin{array}{c}K_{d} / \\
\mathrm{m}^{-1}\end{array}$ \\
\hline 青山湖 & $8.7 \pm 0.6$ & $8.96 \pm 1.90$ & $0.33 \pm 0.08$ & $116 \pm 4$ & $174 \pm 20$ & $50.4 \pm 26.0$ & $96.0 \pm 14.0$ & $61.2 \pm 61.4$ & $4.17 \pm 0.05$ \\
瑶湖 & $8.1 \pm 0.8$ & $8.95 \pm 1.10$ & $0.57 \pm 0.30$ & $149 \pm 16$ & $201 \pm 15$ & $39.7 \pm 21.0$ & $105.0 \pm 34.0$ & $103.6 \pm 42.6$ & $3.42 \pm 1.13$ \\
军山湖 & $7.5 \pm 0.6$ & $7.86 \pm 1.80$ & $1.20 \pm 0.70$ & $55 \pm 0.5$ & $80 \pm 2.5$ & $10.7 \pm 5.0$ & $131.5 \pm 36.0$ & $307.1 \pm 88.4$ & $1.38 \pm 0.16$ \\
\hline
\end{tabular}

$* \mathrm{PAR}$ 为水下 $0.5 \mathrm{~m}$ 处水下有效辐射的实测值.

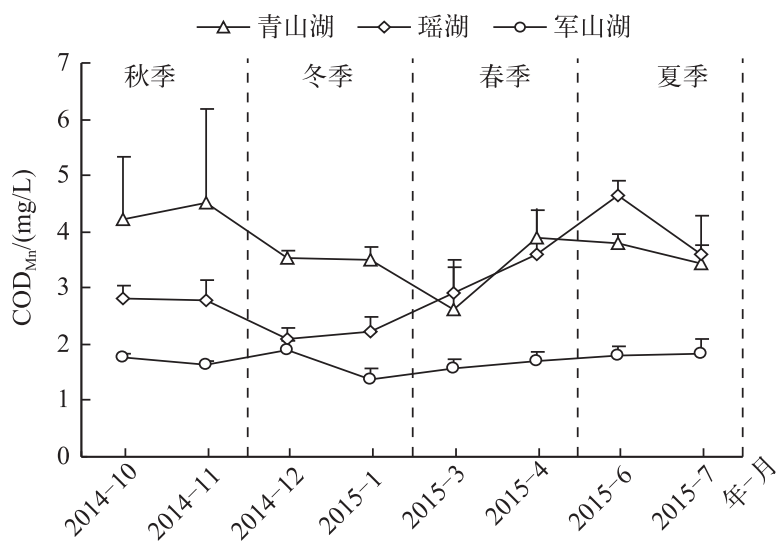

图 2 青山湖、瑶湖和军山湖水柱 $\mathrm{COD}_{\mathrm{Mn}}$ 浓度变化

Fig.2 Changes of $\mathrm{COD}_{\mathrm{Mn}}$ in water column of Lake Qingshan, Lake Yaohu and Lake Junshan

青山湖、瑶湖和军山湖 TN 浓度范围分别为 $0.099 \sim 1.964 、 0.131 \sim 0.435$ 和 $0.042 \sim 0.359 \mathrm{mg} / \mathrm{L}$ ( 图 3a), 除 青山湖和瑶湖分别在 2014 年 10 月和 2015 年 1 月达到最大值,仅达到地表水 V 类和 III类标准外 ( GB $3838-$ $2002)$, 其他月份均达到了地表水 I II 类标准, 军山湖在调查的月份中 TN 浓度达到地表水 I II 类标准, 军山湖与青山湖呈显著差异 $(P<0.05)$, 与瑶湖呈极显著差异 $(P<0.01)$, 青山湖与瑶湖无显著性差异 $(P>$ 0.05 ); TP 浓度范围分别为 $0.071 \sim 0.299 、 0.073 \sim 0.234$ 和 $0.01 \sim 0.071 \mathrm{mg} / \mathrm{L}$ ( 图 3c, 其中青山湖和瑶湖 TP 浓 度超标仅达到地表水 $I V \sim$ 劣 $V$ 标准, 且都表现为冬季降低, 其他季节有所升高, 2 个湖泊之间无显著差异 $(P>$ $0.05)$. 军山湖 TP 浓度在 2015 年 6 月达到最大值 $(0.071 \mathrm{mg} / \mathrm{L})$, 仅达到地表水 $\mathrm{IV}$ 类标准, 其他月份达到 $\mathrm{I} \sim$ III 类标准, 春季和夏季 TP 浓度高于秋季和冬季, 军山湖与其他 2 个湖泊之间均呈极显著差异 $(P<0.01)$. TDN 、TDP 分别是 TN、TP 的重要组成部分, 可被浮游植物直接吸收并加以利用, 是藻类生长最直接的营养盐 来源. 3 个湖泊 TDN 浓度均在秋季达到最大值(图 $3 \mathrm{~b}$ ), 与该季节鱼类捕捞活动增加导致水体中 TDN 浓度升高 有关, 氮的形态主要是可溶性态氮, 仅军山湖与瑶湖呈极显著差异 $(P<0.01)$, 其他湖泊之间无显著差异 $(P>$ 0.05 ); 青山湖和瑶湖的 TDP 浓度范围为 $0.004 \sim 0.059$ 和 $0.003 \sim 0.110 \mathrm{mg} / \mathrm{L}$ (图 3d), 总体波动较大, 军山湖表 现平稳, 磷形态除了军山湖外另外 2 个湖泊主要为颗粒态磷, 3 个湖泊两两之间均呈极显著差异 $(P<0.01)$.

Chl. a 浓度可以在一定程度上表征水体浮游植物的现存量. 青山湖、瑶湖和军山湖的 Chl. a 浓度范围分 别为 $34.65 \sim 184.48 、 7.66 \sim 120.67$ 和 $2.42 \sim 17.41 \mu \mathrm{g} / \mathrm{L}$, 平均值分别为 $94.65 、 60.13$ 和 $8.31 \mu \mathrm{g} / \mathrm{L}$, 水体 $\mathrm{Chl} . \mathrm{a}$ 浓度梯度明显. 各湖泊的 Chl. a 浓度均在冬季达到最低值, 其他季节浮游藻类的生长逐渐复苏. 3 个湖泊的 Chl. a 浓度变化较大 (图 4), 但青山湖与瑶湖之间无显著差异 $(P>0.05)$, 军山湖与其他 2 个湖泊均呈极显著 差异 $(P<0.01)$.

$\mathrm{N} / \mathrm{P}$ 比值对藻类的暴发性生长具有重要作用, 当水体中 $\mathrm{N} / \mathrm{P}$ 比值 $<7, \mathrm{~N}$ 将限制藻类的生长, $N / P$ 比值在 $8 \sim 30$ 为适应藻类生长范围, $\mathrm{N} / \mathrm{P}$ 比值 $>30, \mathrm{P}$ 将成为藻类生长的限制因子 ${ }^{[17]}$. 本研究中青山湖、瑶湖和军山 

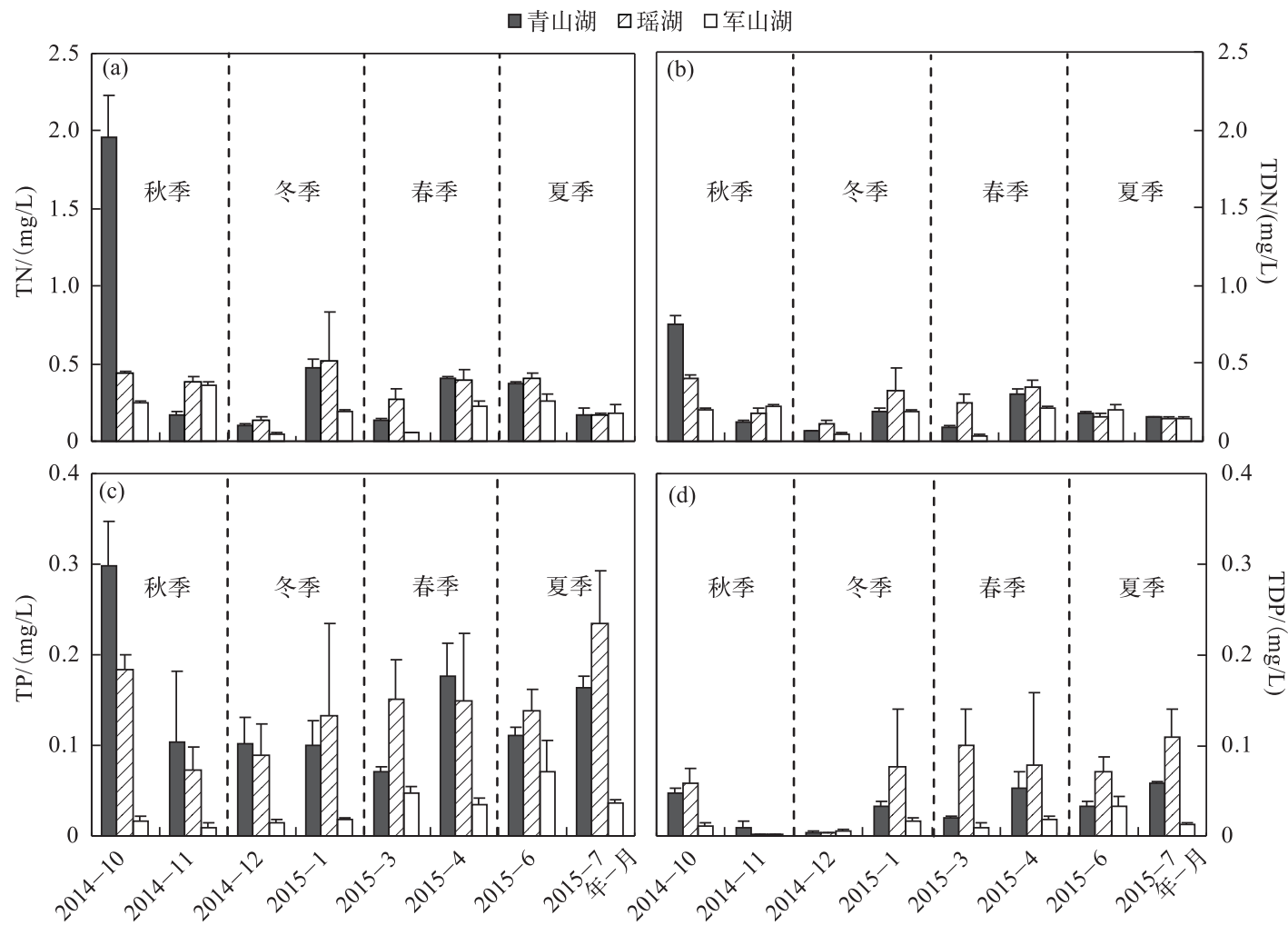

图 3 青山湖、瑶湖和军山湖水柱 N、P 营养盐浓度变化

Fig.3 Changes of N, P nutrients in water column of Lake Qingshan, Lake Yaohu and Lake Junshan

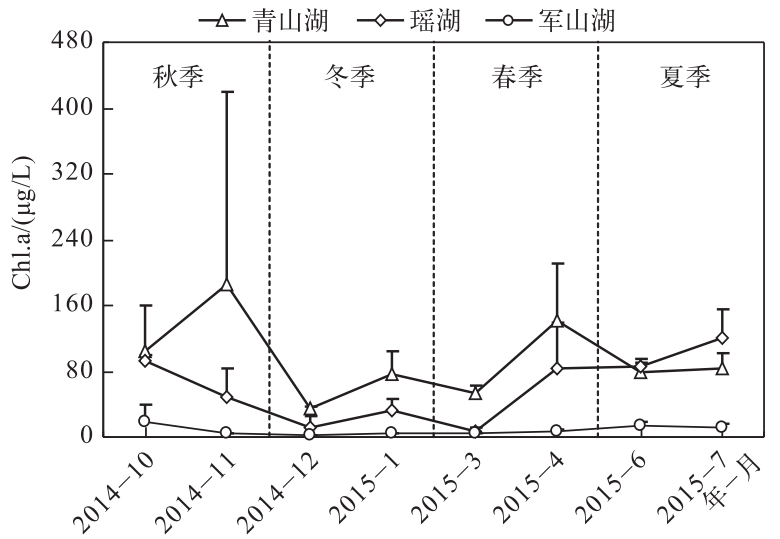

图 4 青山湖、瑶湖和军山湖水柱 Chl.a 浓度变化

Fig.4 Changes of Chl.a concentration in water column of Lake Qingshan, Lake Yaohu and Lake Junshan

湖 N/P 比值范围分别在 1.0 6.7、1.8 5.8 和 3.2 56.6, 青山湖、瑶湖全湖 N/P 比值 $<7$, 表明青山湖和瑶湖藻 类生长可能主要受 $\mathrm{N}$ 限制. 军山湖在 10 月份 $\mathrm{N} / \mathrm{P}$ 比值 $>30$, 表明藻类生长可能主要受 $\mathrm{P}$ 限制, 在 2015 年 11 月份和 2015 年 1 月 $\mathrm{N} / \mathrm{P}$ 比处于适应藻类生长范围内, 其他月份藻类生长可能受 $\mathrm{N}$ 限制. 


\subsection{3 个湖泊水环境营养状态评价}

青山湖、瑶湖和军山湖的 TLI $\left(\sum\right)$ 范围分别为 49.46 68.40、40.41 61.44 和 23.94 41.66, 青山湖除在 2014 年 12 月仅处于中营养外, 其他月份均达到轻度一中度富营养水平, 瑶湖 $T L I(\Sigma)$ 值变化范围较大, 营 养状态在中营养-轻度富营养-中度富营养之间波动变化, 军山湖营养状态处于较低水平, 介于贫-中营养水 平之间, 且呈波动上升的趋中营养态 (图 5). 总体上, 3 个湖泊营养状态水平表现为青山湖 $>$ 瑶湖 $>$ 军山湖, 且在冬季都有所降低. 这可能是因为受到冬季水温低、光照强度底、光照时间短和营养盐输人较少等环境因 素的影响.

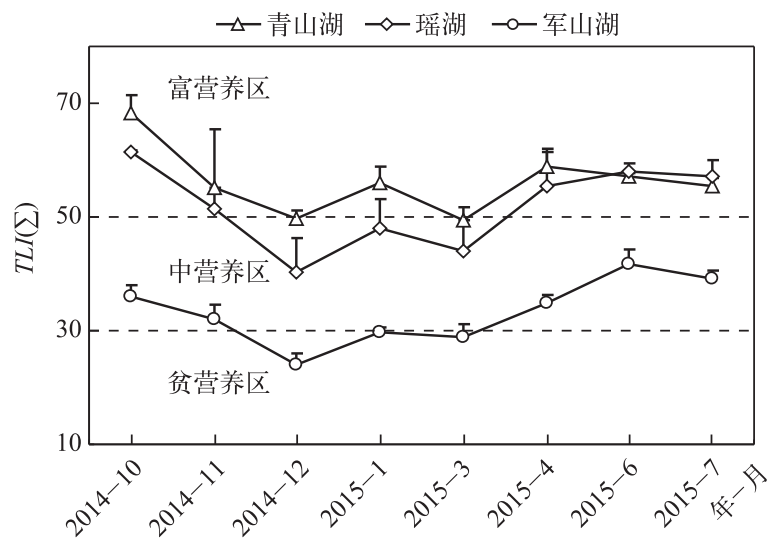

图 5 青山湖、瑶湖和军山湖综合营养状态指数变化

Fig.5 Comprehensive evaluation dynamics of nutritional state in Lake Qingshan, Lake Yaohu and Lake Junshan

\subsection{3 个湖泊 Chl.a 浓度与各营养因子之间的相关关系}

在 3 个湖泊中, Chl.a 浓度与 TN、TP、TDN、TDP 浓度都呈显著正相关 $(P<0.05)$, 其中青山湖和瑶湖 Chl.a 浓度与 TN 、TP 浓度呈极显著正相关 $(P<0.01)$, 青山湖和军山湖水体中 Chl.a 浓度与 TDN、TDP 浓度呈极显 著正相关 $(P<0.01)$; Chl.a 浓度与 $\mathrm{COD}_{\mathrm{Mn}}$ 浓度呈正相关, 仅在瑶湖中呈极显著正相关 $(P<0.01)$, 另外 2 个湖 泊中相关关系均不显著; Chl.a 浓度与 SD 呈负相关, 除青山湖 Chl.a 浓度与 SD 相关性不显著外,另外 2 个湖 泊 Chl.a 浓度与 SD 呈极显著负相关 $(P<0.01)$, Chl.a 浓度与 SD 的相关关系表明,青山湖水体透明度可能主 要受悬浮颗粒物的影响, 与湖区复杂的水环境条件有关, 而浮游藻类可能是导致瑶湖和军山湖水体透明度 降低的主要影响因素; 青山湖和瑶湖中, TP 浓度与 $\mathrm{COD}_{\mathrm{Mn}}$ 、TN 浓度呈显著正相关 $(P<0.05)$, 表明水体中营 养盐可能来自相同的源.

\subsection{3 个湖泊 $T L I(\Sigma)$ 和 N/P 比值 (TDN/TDP 比) 在不同水温中的变化情况}

根据水温高低将 3 个湖泊周年时段分为低、中、高 3 个温度梯度, 分析 3 个温度区间之间湖泊综合营养 状态指数 $T L I(\Sigma)$ 及 N/P 比值 (TDN/TDP 比) 的变化情况 (图 6). 在青山湖, 中温时期的 $T L I(\Sigma)$ 达到最大 值, 低温时期的营养状态优于高温, 中温时期的 $T L I\left(\sum\right)$ 分别与低温和高温时期均存在显著差异, 表明中温 有利于水体的富营养化; 在瑶湖, 中温和高温时期的 $T L I(\Sigma)$ 变化不大, 但在低温环境中, 湖泊水体营养状态 变化明显; 在军山湖, 随着温度的升高, $T L I(\Sigma)$ 逐渐增大, 且 3 个温度梯度两两之间均存在显著差异, 表明军 山湖水体的营养状态在一定程度上依赖于高温环境. 青山湖、瑶湖和军山湖的 N/P 比值范围分别为 $4.26 \sim$ 15.74、1.91 32.97 和 8.80 50.02, 平均值分别为 10.4、19.4 和 24.4. 3 个湖泊均在中温时期 N/P 比值达到最 大值, 且随着温度的升高比值逐渐降低, 在高温时期达到最低值 (图 6). 青山湖和瑶湖 N/P 比值不同的温度 梯度两两之间均存在显著差异, 而军山湖的低温和高温之间差异性不明显, 但都与中温时期的比值存在显 著差异. 
表 33 个湖泊水体各营养因子间相关关系

Tab.3 Pearson correlation coefficients among trophic factors of Lake Qingshan, Lake Yaohu and Lake Junshan

\begin{tabular}{|c|c|c|c|c|c|c|c|}
\hline 湖泊 & 营养因子 & $\mathrm{COD}_{\mathrm{Mn}}$ & $\mathrm{TN}$ & $\mathrm{TP}$ & SD & Chl.a & DTN \\
\hline \multirow[t]{6}{*}{ 青山湖 } & $\mathrm{TN}$ & 0.253 & 1.000 & & & & \\
\hline & $\mathrm{TP}$ & $0.378^{*}$ & $0.530^{* *}$ & 1.000 & & & \\
\hline & SD & -0.060 & -0.215 & $-0.447^{*}$ & 1.000 & & \\
\hline & Chl.a & 0.227 & $0.497^{* *}$ & $0.635^{\text {*** }}$ & -0.313 & 1.000 & \\
\hline & DTN & 0.297 & $0.916^{* *}$ & $0.628^{* * *}$ & -0.172 & $0.535^{* *}$ & 1.000 \\
\hline & DTP & 0.079 & $0.619^{* * *}$ & $0.677^{* * *}$ & -0.137 & $0.531^{* * *}$ & $0.720^{\text {*** }}$ \\
\hline \multirow[t]{6}{*}{ 瑶湖 } & $\mathrm{TN}$ & 0.331 * & 1.000 & & & & \\
\hline & $\mathrm{TP}$ & $0.518^{* * *}$ & $0.313^{*}$ & 1.000 & & & \\
\hline & SD & $-0.406^{* *}$ & -0.281 & $-0.391^{\text {*** }}$ & 1.000 & & \\
\hline & Chl.a & $0.472^{* * *}$ & $0.393^{* *}$ & $0.425^{\text {*** }}$ & $-0.685^{* *}$ & 1.000 & \\
\hline & DTN & 0.195 & $0.652^{* *}$ & 0.276 & -0.020 & 0.160 & 1.000 \\
\hline & DTP & $0.493^{* *}$ & 0.260 & $0.809^{* * *}$ & 0.009 & $0.298^{*}$ & 0.416 \\
\hline \multirow[t]{6}{*}{ 军山湖 } & $\mathrm{TN}$ & -0.059 & 1.000 & & & & \\
\hline & $\mathrm{TP}$ & 0.048 & -0.092 & 1.000 & & & \\
\hline & SD & $-0.363^{*}$ & $-0.512^{* *}$ & -0.211 & 1.000 & & \\
\hline & Chl.a & 0.285 & $0.531^{* *}$ & $0.364^{*}$ & $-0.677^{* *}$ & 1.000 & \\
\hline & DTN & -0.012 & $0.858^{* *}$ & -0.155 & -0.287 & $0.427^{\text {** }}$ & 1.000 \\
\hline & DTP & 0.065 & 0.218 & $0.590^{* * *}$ & -0.104 & $0.589^{* *}$ & 0.301 \\
\hline
\end{tabular}

$* P<0.05, * * P<0.01$.
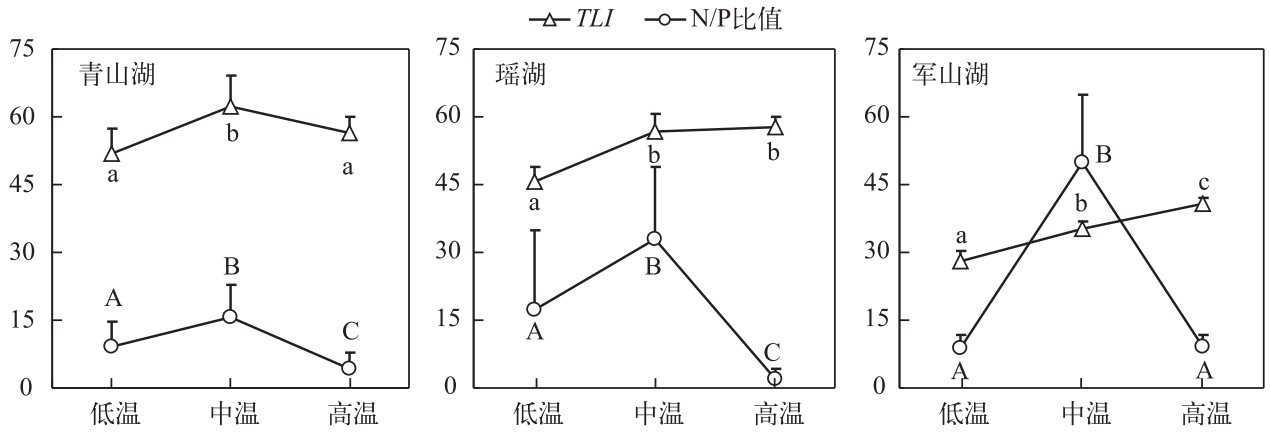

图 63 个湖泊 $T L I 、 \mathrm{~N} / \mathrm{P}$ 比值随温度的变化情况

( 水温 $\mathrm{T}<15^{\circ} \mathrm{C}$ 为低温, $15^{\circ} \mathrm{C} \sim 25^{\circ} \mathrm{C}$ 为中温, $\mathrm{T}>25^{\circ} \mathrm{C}$ 为高温,

不同字母表示差异性显著,各湖泊之间无差异性比较)

Fig.6 TLI and the ratio of N/P variations with temperature in Lake Qingshan, Lake Yaohu and Lake Junshan

\section{3 讨论}

\subsection{3 个湖泊水体环境特征参数的周年动态规律分析}

水体透明度主要取决于湖泊水文条件和含沙量, 同时也受到水体藻类的影响 ${ }^{[18-19]}$, 在所调查的 3 个湖 泊中, 军山湖地处农村偏僻地区, 受人为影响较小、植被覆盖率高, SD 显著高于其他湖泊. 浊度代表水体悬 浮颗粒物含量的高低, 青山湖和瑶湖的浊度分别达到了 50.4 和 39.7 NTU,2 个湖泊都属于省级风景游览区, 湖区岸线发育程度底, 湖滨带人为活动频繁从而导致湖泊水体中悬浮物含量高. 同时, Chl. a 浓度可以在一 定程度上表征水体浮游植物的现存量, 青山湖和瑶湖的 Chl. a 浓度分别达到 94.65 和 $60.13 \mu \mathrm{g} / \mathrm{L}$, 因此湖泊 
浮游藻类的大量繁殖可能是致使透明度下降的又一重要原因.

氮、磷是浮游植物生长所需的生源要素, 当水体中氮、磷营养盐浓度达到一定程度时, 在合适的温度和 光照等环境条件下会导致水体中的浮游植物迅速增长, 甚至会导致蓝藻水华暴发. 一般认为, 当水体中 $\mathrm{TN}$ 、 $\mathrm{TP}$ 浓度分别达到 0.20 和 $0.02 \mathrm{mg} / \mathrm{L}$ 以上时, 水体存在发生富营养化的风险 ${ }^{[20]}$, 在所调查的 3 个湖泊中, 青 山湖 ( TN : $0.516 \mathrm{mg} / \mathrm{L}, \mathrm{TP}: 0.138 \mathrm{mg} / \mathrm{L}$ ) 和瑶湖 ( TN : $0.362 \mathrm{mg} / \mathrm{L}, \mathrm{TP}: 0.131 \mathrm{mg} / \mathrm{L}$ ) 的氮、磷营养盐浓度均远高 于水体富营养化的氮、磷阈值, 表明青山湖和瑶湖水体为浮游藻类的生长提供了充足营养盐, 且在一定的环 境条件驱动下 (合适的温度和光照) 藻类水华风险将加大. 青山湖和瑶湖水体中 TP 浓度较高, 仅达到地表水 $\mathrm{IV} \sim$ 劣 $\mathrm{V}$ 标准, 相比其他营养盐, 2 个湖泊的 TP 污染最严重. 根据 N/P 比值可知, 青山湖和瑶湖全湖 N/P 比< 7 , 低于长江中下游的大部分湖泊 ${ }^{[21]}$, 表明相比于 TN 而言, 水体中 TP 浓度充足. 军山湖全年 TN 浓度为 $0.197 \mathrm{mg} / \mathrm{L}$, 处于 I 类水质标准, 无明显季节变化趋势; TP 浓度为 $0.03 \mathrm{mg} / \mathrm{L}$, 处于 III 类水质标准, 春季和夏 季 TP 浓度高于秋季和冬季, 这可能是由于环湖周边农业活动增加导致水体营养盐升高有关.

水体环境中适宜于藻类生长的水温条件一般为 $15 \sim 25^{\circ} \mathrm{C}$, 冬季 Chl. a 浓度较低可能与水温低于适宜藻 类生长温度有关 ${ }^{[22]}$. 青山湖中, 丰富的营养盐给水体浮游植物生长提供了充足的氮磷营养来源, 在温度适 宜且光照充足的秋季环境条件下必然导致浮游藻类大量繁殖, 藻类的生长速度势必要大于其他季节. 在瑶

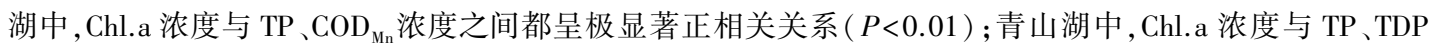
浓度之间呈极显著正相关关系, 即随着营养盐浓度的增加, 水体浮游藻类数量随即逐渐增多. 瑶湖水环境中 $\mathrm{TP} 、 \mathrm{COD}_{\mathrm{Mn}}$ 浓度和军山湖水环境中 TP、TDP 浓度在夏季达到最大值, 因而瑶湖和军山湖在夏季时期 Chl. a 浓 度要高于其他季节, 这可能与营养盐浓度升高有关. 3 个湖泊的 Chl.a 浓度均在冬季达到最低值, 其他季节 有所复苏, 这可能与冬季特殊环境条件有关. 冬季为枯水期, 具有水温低、光照强度低、日照短、营养盐输人 较少等特点, 不能满足绝大多数浮游植物的生长所需, 仅能满足少数耐寒植物的生长, 导致水体中浮游植物 数量减少.

\subsection{3 个湖泊富营养化成因及驱动因子分析}

对于不同的水域, 由于区域地理特性、自然气候条件、水生生态系统和污染特征等诸多差异, 会出现不 同的富营养化状况 ${ }^{[23]}$. 本研究 3 个湖泊中, 由于区域位置、人为干扰、利用类型上存在不同之处,富营养化状 态呈现出明显的梯度差异. 整体上, 青山湖富营养化程度最严重, 已是一个稳定的中度富营养化湖泊; 其次 为瑶湖, 已处于轻度富营养化的边缘; 军山湖则相对较轻, 呈波动上升趋中营养态. 从湖泊的水文条件来看, 3 个湖泊的源水主要来自于天然降水, 且只到丰水期时才放水泄洪, 水循环周期长, 容易造成水体的营养盐 累积, 尤其青山湖和瑶湖, 湖泊面积小且水深小于 $2 \mathrm{~m}$, 水体环境承载能力差, 导致湖泊水体水质恶化. 近年 来洞庭湖水体 TN、TP 污染严重, 但长期稳定在中营养水平, 这与其特定的水文情况 (换水周期 $18.2 \mathrm{~d}$ ) 有很 大关系 ${ }^{[18]}$, 因此, 对于青山湖和瑶湖具有特殊水文条件且自净能力弱的浅水湖泊而言, 水体中营养盐浓度的 升高, 极易导致富营养化的发生. 从污染源分析来看, 青山湖和瑶湖富营养化主要来自于外源污染. 其中青 山湖属于城市内陆景观湖泊, 湖岸线城市建筑多, 人口密集, 城市活动所产生的污染物随地表径流直接进人 青山湖水体, 同时, 污染严重的玉带河不断向湖泊中输人营养盐, 是导致青山湖富营养化的主要原因. 瑶湖 污染源众多, 点源污染是水体营养物质的主要来源, 其中以周边高校生活污水污染最为严重, 占整个点源污 染的 $57 \%$. 瑶湖流域内农业生产活动如农村生活污水、水厂养殖、畜禽养殖等所产生的面源污染也是导致瑶 湖富营养化的重要原因. 军山湖相比于其他湖泊具有优越的地位位置, 地处农村偏远地区, 湖滨带岸线发育 程度高, 受人为影响小, 人湖污染物量少, 再加上湖泊自身水文条件, 整体水质较好. 然而军山湖的污染物主 要来自于水产养殖所产生的氮、磷营养盐, 随着水产养殖规模扩大, 围网/围栏养殖面积的扩张, 势必增加水 体中营养盐浓度, 且湖区周边日趋严重的面源污染也将加快军山湖的富营养化进程. 如夏季军山湖水体的 营养状态指数要高于其他季节, 这可能是由于湖区周边农田施肥导致水体中营养盐升高所致.

水体富营养化的发生所必需的条件主要有 3 个方面的影响因素 ${ }^{[24-25]}$ : 总氮、总磷等营养盐相对比较充 足; 缓慢的水流流态 (流速、水深等); 适宜的环境条件 (水温、光照等). 当水体中的营养物质输人输出失调, 将导致某种优势藻类大量繁殖, 最终破坏系统的能量流动和物质循环, 使整个水体环境系统出现失衡 ${ }^{[26]}$. 根据单因子营养状态指数分析, 3 个湖泊中 Chl.a 浓度的营养状态指数均高于其他指标, 表明 Chl.a 浓度是 3 
个湖泊中影响水体富营养化程度最重要的指标. 根据相关性分析可知, Chl. a 浓度与 TN 、 TP 浓度均呈显著正 相关 $(P<0.01)$, 因此随着湖泊中氮、磷营养盐浓度的升高, 水体中浮游藻类生物量则相应增加, 使整个水环 境系统遭受破坏, 加剧了湖泊的富营养化. 同时, 水温也是影响 3 个湖泊富营养化的重要环境因素. 在营养 盐充足的情况下, 水体富营养化依赖于环境条件水温的变化. 在青山湖中, 中温水体环境有利于湖泊的富营 养化; 瑶湖在低温时期营养状态指数最低, 中温和高温环境都适宜水体发生富营养化; 而军山湖的营养状态 则依赖于高温环境, 3 个湖泊的富营养化程度分别取决于不同的水温环境, 可能与各湖泊的地理位置、水深、 营养盐浓度等因素有关.

\subsection{N/P 比值 ( TDN/TDP 比) 的新发现}

诸多研究中常以氮磷比 ( TN/TP) 为指标来判别浮游植物营养限制类型, 但是不同学者提出的氮磷比阈 值差异很大, 如 10 17、10 30 和 7 15 $5^{[27-29]}$, 也因此收到诸多质疑. 王海军等通过对长江中下游流域 45 个 浅水湖泊的 TN 、 TP 与 Chl. a 浓度之间进行分析, 结合国外最新研究进展, 指出浅水湖泊中氮磷比并不能直接 反映浮游植物的营养限制类型 ${ }^{[30-31]}$. TDN 、TDP 是湖泊水体中氮磷营养盐结构的重要组成部分, 在浮游藻类 的生长过程中可被直接吸收并加以利用, 因此, TDN 与 TDP 对藻类的生长影响比其他形式的营养盐更为敏 感. 在本研究中, 探讨富营养化程度梯度明显的 3 个湖泊的 N/P 比值, 以新的研究视角分析湖泊中氮磷比对 湖泊富营养化机理提供参考. 对于富营养化湖泊, 水体中 $\mathrm{N} / \mathrm{P}$ 比值对应参考值为 10 左右; 对于中营养-轻度 富营养化湖泊, N/P 比值比参考值可能为 20 左右; 而对于中营养状态湖泊而言, 水体中的 N/P 比值参考值 可能为 25 左右. 当湖泊水体中的 N/P 比值变化, 根据参考值可判断湖泊水体营养状态的变化趋势, 提前预 警湖泊富营养化的发生. 尽管这一推论还待进一步验证, 但这也为认识湖泊富营养化转变及机理提供新的 研究视角, 为湖泊管理提供优化指标.

\section{4 对“三湖”富营养化治理与保护的启示}

湖库富营养化的最直接原因是营养盐输人的增加和积蓄, 其中氮、磷影响最突出, 因此控制水体富营养 化的关键在于流域污染防治 ${ }^{[32]}$. 青山湖为城市内陆湖泊, 受到周边人类活动以及南昌市污染严重的玉带河 的影响, 现已处于稳定的富营养化状态. 目前, 相关主管部门正对玉带河环境综合整治(如截污、清淤和水体 净化), 有效拦截流人青山湖的污染物的量, 这将对会对青山湖不断提高的富营养水平有所缓解. 瑶湖的水 质则处于剧烈波动的变化状态, 这主要是由于受到以周边高校生活污水为主的点源污染及以分散式畜禽养 殖为主的面源污染的双重影响. 因此, 着重瑶湖流域范围内排污沟渠的治理及加强整治规范畜禽养殖业将 有利于改善湖泊水质, 减缓瑶湖水体富营养化. 同时, 瑶湖处于城市城乡结合部, 湖滨高大建筑极少, 水体普 遍不深于 $4 \mathrm{~m}$, 现受风浪的影响较大. 尤本胜等 ${ }^{[33]}$ 对风浪作用下太湖草型湖区沉积物的再悬浮与沉降的模拟 实验表明, 中 $(5.1 \mathrm{~m} / \mathrm{s}) 、 小(3.2 \mathrm{~m} / \mathrm{s})$ 风速下, 水体 N、P 浓度都呈显著增大趋势; 朱广伟等 ${ }^{[34]}$ 在强 $(12 \mathrm{~m} / \mathrm{s})$ 、弱 ( $3 \mathrm{~m} / \mathrm{s}$ 以下) 风浪下对太湖梅梁湾一浅水区 (水深 $\leqslant 2 \mathrm{~m}$ ) 的营养盐、悬浮物等动态研究发现, 强风浪期间与 弱风浪期间相比, 湖水中悬浮物浓度提高了 10 倍, TP 浓度提高了 3.6 倍, 因此风浪的作用可能引起水柱氮、 磷等营养盐浓度呈不稳定变化, 从而导致瑶湖富营养化水平呈明显的时空波动. 军山湖水质整体较好, 湖泊 沿岸基本为荒山或杂草甸对湖泊营养输人的贡献较小. 但是军山湖鱼类和螃蟹养殖对湖泊水质带来一定影 响, 控制军山湖的养殖规模和范围有利于军山湖的水环境保护. 在富营养化湖泊中, 控制和削减磷营养盐输 人的同时, 应考虑如何有效降低氮的输人, 并需着重控制中温季节 (水温 $15 \sim 25^{\circ} \mathrm{C}$ ) 的营养输人和富营养化 风险防控; 在中营养湖泊则应在控制磷的输人和消减水柱氮上进行系统调控, 尤其重视高温季节 (水温> $25^{\circ} \mathrm{C}$ ) 的防控与预警. 以上措施可为保护和治理鄱阳湖外围代表性亚热带浅水湖泊的水环境提供重点方向 与新型管理思路.

另一方面, 湖泊的水生态修复工程也可作为鄱阳湖前置库的治理研究试点, Scheffer 等 ${ }^{[35-36]}$ 提出的 “浅 水湖泊稳态转换” 理论阐明了在适当的营养条件下 ( TP $=0.05 \sim 0.15 \mathrm{mg} / \mathrm{L})$ 浅水湖泊可处于 2 个不同的状 态, 浮游植物占优势的 “浊水态” 和水生植物占优势的 “清水态”. 另有学者从实践分析上给出了具体的赋 值, 如羊向东 ${ }^{[37]}$ 等提出湖泊由草型阶段转变为藻型阶段 TP 浓度变化范围在 $0.07 \sim 0.11 \mathrm{mg} / \mathrm{L}$ 之间, Wang 等 ${ }^{[38]}$ 的研究也指出, 浅水湖泊由 “清水态” 转换为 “浊水态” 的 TP 浓度阈值为 $0.08 \sim 0.12 \mathrm{mg} / \mathrm{L}$, 而逆向转换 的浓度范围为 $0.04 \sim 0.06 \mathrm{mg} / \mathrm{L}$. 本研究青山湖和瑶湖现处于以浮游藻类为主的 “浊水态” 系统环境, 面临着 
水体中沉水植物严重缺乏、物种多样性下降、群落结构简单化等一系列湖泊生态问题. Lazzaro ${ }^{[39]}$ 认为水体中 磷浓度应控制在 $0.100 \mathrm{mg} / \mathrm{L}$ 以下, 有利于沉水植物发展与湖泊恢复, 而青山湖和瑶湖水体 TP 浓度分别为 0.138 和 $0.131 \mathrm{mg} / \mathrm{L}$, 不利于水生植物的生态修复. 因此, 对于磷污染严重的浅水湖泊而言, 应把工作重点放 在污染控制和环境改善上, 引导生态系统向草型生态系统发展, 为湖泊的生态修复提供有利条件. 而对于 $\mathrm{TP}$ 浓度低且沉水植被极度贵乏的浅水湖泊而言, 可通过开展生态修复技术来改善水质,并逐步建立以沉水 植被占优势的清水稳态, 以增强浅水湖泊系统稳定性和优质状态的回复力.

\section{4 结论}

1) 青山湖和瑶湖水体 TN、TP 均来自相同的污染源, 且都高于水体发生富营养化的限制值, 存在发生富 营养化的风险. 相比于其他营养盐, 青山湖和瑶湖 TP 污染最为严重, 仅达到地表水 $\mathrm{IV}$ 劣 V 类标准. 军山湖 $\mathrm{TN}$ 浓度无明显季节变化趋势, TP 浓度春季和夏季高于秋季和冬季.

2) 3 个湖泊的富营养化程度表现为青山湖 $>$ 瑶湖 $>$ 军山湖, 其中青山湖由于外源性污染严重已成为一个 稳定的富营养化湖泊, 营养状态达到轻度富营养 中度富营养之间; 瑶湖由于周边污染物间隙式的排人且受 风浪的影响导致富营养呈波动变化状态, 处在中营养 中度富营养之间波动变化, 是一个营养状态不稳定的 湖泊; 军山湖地处农村偏僻地区, 湖泊沿岸基本为荒山或杂草甸, 对湖泊营养输人的贡献较小, 是一个稳定 的低营养湖泊,介于贫营养 中营养状态之间. 3 个湖泊的浮游藻类生长均与 TN、TP 浓度关系密切.

3) 水温是 3 个湖泊富营养化的重要影响因子, 各湖泊的富营养化程度分别取决于不同的水温环境, 可 能与各湖泊地理位置、水深、营养盐浓度等因素有关.

4) 整体来说, 水柱氮是影响 3 个湖泊水环境特征的主导因子之一, 磷是 2 个富营养化湖泊主导影响因 子, 对于富营养化湖泊控制和削减磷营养盐输人的同时, 应考虑如何有效降低氮的输人, 对于中营养湖泊应 在控制磷的输人和削减水柱氮上进行系统调控, 将是保护和治理 3 个湖泊水环境的重点方向. 对于磷污染 严重的浅水湖泊 (青山湖和瑶湖), 应先把工作重点放在污染控制和环境改善上,并着重控制中温季节 (水温 $15 \sim 25^{\circ} \mathrm{C}$ ) 的营养输人和富营养化风险防控, 而对于 TP 浓度低且沉水植物匮乏的浅水湖泊而言, 可通过开 展生态修复技术来改善水质,并逐步建立以沉水植被占优势的清水稳态, 以增强浅水湖泊系统稳定性和优 质状态的回复力.

致谢: 感谢江西省环境保护科学研究院分析实验室的周曼琳和周东华化学分析师在水化分析上提供的帮 助、院水环境研究所的吴俊伟助理工程师在 ArcGIS 作图上提供的帮助、邹斌春和陆友伟师兄在实验分析和 野外采样上提供的帮助;对叶鈢、杨旭焕、杨文生等在赣高校同学在野外采样中的协作、南昌大学鄱阳湖环 境与资源利用教育部重点实验室何亮助理研究员提供的宝贵意见一并表示感谢.

\section{5 参考文献}

[ 1 ] ILEC/Lake Biwa Research Institute. Survery of the State of the World's Lake. Volumes I-IV. International Lake Environment Committee, Ostu and United Nations Environment Programme, Nairobi, 1988 - 1993.

[ 2 ] Xu Qigong, Cao Jinling, Gao Rutai et al. Trend of water quality deterioration and eutrophication control phases partition in China. Environmental Science \& Technology, 2011,34(11): 147-151 (in Chinese with English abstract). [许其功, 曹金 玲, 高如泰等. 我国湖泊水质恶化趋势及富营养化控制阶段划分. 环境科学与技术, 2011, 34(11): 147-151.]

[ 3 ] Jin Xiangcan. The key scientific problems in lake eutrophication studies. Acta Scientiae Circumstantiae, 28(1): 21-23(in Chinese with English abstract). [ 金相灿. 湖泊富营养化研究中的主要科学问题——代 “湖泊富营养化研究” 专栏序 言. 环境科学学报, 2008, 28(1): 21-23.]

[ 4 ] Ma Jing'an, Li Hongqing. Preliminary discussion on eutrophication status of lakes, reservoirs and rivers in China and overseas. Resources and Environment in the Yangtze Basin, 2002, 11(6) : 575-578(in Chinese with English abstract). [马经 安, 李红清. 浅谈国内外江河湖库水体富营养化状况. 长江流域资源与环境, 2002, 11(6) : 575-578.]

[ 5 ] Hu Chunhua, Zhou Wenbin, Wang Maolan et al. Inorganic nitrogen and phosphate and potential eutrophication assessment in Lake Poyang. J Lake Sci,2010,22(5) :723-728(in Chinese with English abstract). DOI: 10.18307/2010.0514. [ 胡春 华, 周文斌, 王毛兰等. 鄱阳湖氮磷营养盐变化特征及潜在性富营养化评价. 湖泊科学, 2010, 22(5) : 723-728.]

[ 6 ] Ding Jianhua, Yang Wei, Jin Xianwen et al. Community structure of macrozoobenthos and biological evaluation of water 
quality in lower reaches of Ganjiang River. J Lake Sci,2012,24(4) :593-599( in Chinese with English abstract). DOI: 10. 18307/2012.0413. [丁建华, 杨威, 金显文等. 赣江下游流域大型底栖动物群落结构及水质生物学评价. 湖泊科学, 2012, 24(4) : 593-599.]

[ 7 ] Wang ML, Luo B, Zhou WB. Calculation and analysis of the water environment capacity for the Yuanhe River in Jiangxi Province, China. Advanced Materials Research, 2011, 281(137) : 137-140.

[ 8 ] Wang Tao, Zhang Meng, Zhang Zhu et al. Calculation of water environmental capacity based on control unit-A case study of the Jinjiang River. Resources and Environment in the Yangtze Basin, 2012, 21(3) : 283-287(in Chinese with English abstract). [王涛, 张萌, 张柱等. 基于控制单元的水环境容量核算研究: 以锦江流域为例. 长江流域资源与环境, $2012,21(3): 283-287$.]

[ 9 ] Dai Guofei, Zhang Meng, Feng Minglei et al. Analysis of cyanobacteria bloom in Nanjishan Natural Reserve in Lake Poyang. Ecological Science, 2015, 34(4) : 26-30(in Chinese with English abstract). [ 戴国飞, 张萌, 冯明雷等. 鄱阳湖南 矶湿地自然保护区蓝藻水华状况与成因分析. 生态科学, 2015, 34(4) : 26-30.]

[10] Wang Shengrui, Ni Zhaokui, Chu Zhaosheng et al. Studies on the change of the river-lake relationship and its impact on water environment in Lake Poyang. Acta Scientiae Circumstantiae, 2015,35(5) : 1259-1264(in Chinese with English abstract). DOI : 10.13671/j.hjkxxb.2014.1050. [王圣瑞, 倪兆奎, 储昭升等. 江湖关系变化及其对鄱阳湖水环境影响 研究. 环境科学学报, 2015, 35(5): 1259-1264. ]

[11] Chen Yang. Study on relationship between water eutrophication and environmental factors in Yao Lake[Dissertation]. Nanchang: East China Jiaotong University, 2012(in Chinese with English abstract). [陈杨. 瑶湖水体营养化现状及其与环 境因子关系的研究 [学位论文]. 南昌: 华东交通大学, 2012.]

[12] Liu Xia, Qian Kuimei, Tan Guoliang et al. Phytoplankton community structure and its succession in isolated lakes of Poyang-Lake Junshan. Environmental Science, 2014, 35(7) : 2557-2564(in Chinese with English abstract). DOI: 10.13227/ j. hjkx.2014.07.017. [刘霞, 钱奎梅, 谭国良等. 鄱阳湖阻隔湖泊浮游植物群落结构演化特征: 以军山湖为例. 环境 科学, 2014, 35(7): 2557-2564.]

[13] Fan Hua, Ji Xiaoyan, Feng Minlei et al. An estimation on agriculture non-point source pollution input load of nitrogen and phosphorus in Lake Junshan basin. Environmental Pollution \& Control, 2012,34(1): 91-96(in Chinese). [樊华, 吉晓 燕, 冯明雷等. 军山湖流域农业非点源污染氮、磷人湖负荷估算. 环境污染与防治, 2012, 34(1) : 91-96.]

[14] State Environmental Protection Administration of China (SEPA) ed. Water and wastewater monitoring analysis method (Fourth Edition). Beijing: China Environmental Science Press, 2002(in Chinese). [ 国家环境保护总局. 水和废水监测 分析方法(第四版). 北京: 中国环境科学出版社, 2002.]

[15] Wang Mingcui, Liu Xueqin, Zhang Jianhui. Evaluate method and classification standard on lake eutrophication. Environmental Monitoring in China, 2002, 18(5): 47-49(in Chinese with English abstract). [王明翠, 刘雪芹, 张建辉. 湖泊 富营养化评价方法及分级标准. 中国环境监测, 2002, 18(5): 47-49.]

[16] Liu Jiankang ed. Ecological research of east lake (II). Beijing: Science Press, 1995: 63-226(in Chinese). [ 刘建康. 东 湖生态学研究 (二). 北京: 科学出版社, 1995: 63-226.]

[17] Peng Jinxin, Chen Huijun eds. Eutrophication and prevention. Beijing: China Environmental Science Press, 1988: 15-47 (in Chinese). [彭近新, 陈慧君. 水质富营养化与防治. 北京:中国环境科学出版社, 1988: 15-47.]

[18] Huang Daizhong, Wang Qun, Li Liqiang et al. Change of water quality and eutrophic state in recent 20 years of Dongting Lake. Research of Environmental Sciences, 2013, 26( 1) : 27-33(in Chinese with English abstract). DOI : 10.13198/j.res. 2013.01.31.huangdzh.008. [黄代中, 万群, 李利强等. 洞庭湖近 20 年水质与富营养化状态变化. 环境科学研究, 2013, 26(1): 27-33.]

[19] Cai Jinbang, Li Wenqi. Limiting factors of eutrophication in Yanghe Reservoir. Water Resources Protection, 2007, 23(3): 52-55 (in Chinese with English abstract). [ 蔡金傍, 李文奇. 洋河水库富营养化限制性因子分析. 水资源保护, 2007, $23(3): 52-55$. ]

[20] Jin Xiangcan, Liu Hongliang, Tu Qingying et al eds. The investigation Chinese lake eutrophication. Beijing: China Environmental Science Press, 1990: 68-70(in Chinese). [ 金相灿, 刘鸿亮, 屠清瑛等. 中国湖泊富营养化调查. 北京: 中 国环境科学出版社, 1990: 68-70.]

[21] Wu Shikai. Ecological studies on TN:TP ratio, phytoplankton and microcystins in 33 shallow lakes in the middle and lower reaches of the Yangtze River[Dissertation]. Wuhan: Institute of Hydrobiology, Chinese Academy of Sciences, 2009(in Chinese with English abstract). [ 吴世凯. 长江中下游地区 33 个浅水湖泊的氮磷比、浮游植物和微囊藻毒素的生态 学研究 [学位论文].武汉: 中国科学院水生生物研究所, 2009.]

[22] Zhang Sheng, Song Dan, Zhang He et al. Trophic status analysis of the upper stream and backwater aera in typical tributa- 
ries three Gorges Reservoir. J Lake Sci, 2010, 22(2) : 201-207( in Chinese with English abstract). DOI: 10.18307/2010. 0208. [ 张晟, 宋丹, 张可等. 三峡水库典型支流上游区和回水区营养盐状态分析. 湖泊科学, 2010, 22(2) : 201-207.]

[23] Zhang Sheng, Li Chongming, Zheng Binghui et al. Trophic states and nutrient output of tributaries in Three Gorges Reservoir area. Environmental Science, 2007, 28(3) : 500-505(in Chinese with English abstract). [张易, 李崇明, 郑丙辉等. 三峡库区次级河流营养状态及营养盐输出影响. 环境科学, 2007, 28(3): 500-505.]

[24] Ye Min, Hong Yiping, Peng Shenghua. Study of the eutrophication trend in the three Gorges Reservoir. In: Huang Zhenli ed. China Environmental Hydraulics 2002. Beijing: China Water \& Power Press, 2002: 26-30(in Chinese). [叶闽, 洪 一平, 彭盛华. 三峡水库水体富营养化的潜势研究. 见: 黄真理编. 中国环境水力学 2002. 北京: 中国水利水电出 版社, 2002: 26-30.]

[25] Li Jinxiu, Liao Wengen. On the prediction methods for eutrophication in the three Gorges Reservoir area. In: Huang Zhenli ed. China Environmental Hydraulics 2002. Beijing: China Water \& Power Press, 2002: 37-42(in Chinese). [李锦秀, 廖文根. 三峡库区富营养化预测方法探讨. 见: 黄真理编. 中国环境水力学 2002. 北京: 中国水利水电出版社, 2002: 37-42.]

[26] Wang Meng, Wu Hongjuan, Ma Jingan. Causes and characteristics of the eutrophication in large reservoirs in the Yangtze basin. Resources and Environment in the Yangtze Basin, 2004, 13(5): 477-481 (in Chinese with English abstract). [王 孟, 邬红娟, 马经安. 长江流域大型水库富营养化特征及成因分析. 长江流域资源与环境, 2004, 13 ( 5): 477-481.]

[27] Sakamoto M. Primary production by phytoplankton community in some Japanese lakes and its dependence on lake depth. Archiv fuir Hydrobiologie, 1966, 62: 1-28.

[28] Huber WC, Brezonik PL, Heany JP et al. A classification of Florida lakes. Department of Environmental Engineering and Sciences, University of Florida, Gainesville, Fl orida, USA, 1982.

[29] OECD. Eutrophication of Waters. Monitoring, Assessment and control, OECD, 2006.

[30] Wang HJ, Liang XM, Jiang PH et al. TN:TP ratio and plantivorous fish do not affect nutrient-chlorophyll relationships in shallow lakes. Freshwater Biology, 2008, 53: 935-944.

[31] Wang Haijun, Wang Hongzhu. Foucing on phosphorus control and relaxing nitrogen emission reduction should be more needed in eutrophication treatment. Progress in Natural Science, 2009, 19(6) : 599-604(in Chinese). [王海军, 王洪铸. 富营养化治理应放宽控氮、集中控磷. 自然科学进展, 2009, 19(6) : 599-604.]

[32] Zhang Meng, Zhu Guorong, Zhou Min et al. Eutrophication assessment and estimation of water environmental capacity in lake Xiannv of Jiangxi. Resources and Environment in the Yangtze Basin, 2015, 24(8) : 1395-1403( in Chinese with English abstract). DOI : 10.11870/cjlyzyyhj201508019. [张萌, 祝国荣, 周慜等. 仙女湖富营养化特征与水环境容量核 算. 长江流域资源与环境, 2015, 24(8): 1395-1403.]

[33] You Bensheng, Wang Tongcheng, Fan Chengxin et al. The simulation of ammonia nitrogen and phosphorus loading variations under the influence of wind-wave in aquatic macrophytes areas of Lake Taihu. China Environment Science, 2008, 28 (1)：33-38(in Chinese with English abstract). [尤本胜, 王同成, 范成新等. 风浪作用下太湖草型湖区水体 N、P 动 态负荷模拟. 中国环境科学, 2008, 28(1):33-38.]

[34] Zhu Guangwei, Qin Boqiang, Gao Guang. Vertical distribution of the concentrations of phosphorus and suspended solid in Taihu lake affected by wind-induced wave. Advances in Water Science, 2004, 15(6) : 775-779(in Chinese with English abstract). [ 朱广伟, 秦伯强, 高光. 强弱风浪扰动下太湖的营养盐垂向分布特征. 水科学进展, 2004, 15(6): 775-779. ]

[35] Scheffer M, Hosper H, Meijer ML et al. Alternative equilibria in shallow lakes. Trends in Ecology \& Evolution, 1993, 8: 275-279.

[36] Scheffer M. Alternative attractors of shallow lakes. The Scientific World, 2001, (1) : 254-263.

[37] Yang XD, Shen J, Dong XH et al. Historical trophic evolutions and their ecological responses from shallow lakes in the middle and lower reaches of the Yangtze River: Case studies on Longgan Lake and Taibai Lake. Science in China Series D, 2006, 49( suppl. 1) : 51-61.

[38] Wang HJ, Wang HZ, Liang XM et al. Total phosphorus thresholds for regime shifts are nearly equal in subtropical and temperate shallow lakes with moderate depths and areas. Freshwater Biology, 2014,59: 1659-1671.

[39] Lazzaro X. Do the trophic cascade hypothsis and classical biomanipulation approaches apply to trophical lakes and reservoirs? Verhandlungen des Internationalen Verein Limnologie, 1997, 26: 719-730. 